\title{
Teachers' Views over the Workout Strategies for Helping Students Motivate Themselves in the Classroom
}

\author{
Fethi Kayalar \\ Faculty of Education, Erzincan University, Turkey
}

Copyright $(2016$ by authors, all rights reserved. Authors agree that this article remains permanently open access under the terms of the Creative Commons Attribution License 4.0 International License

\begin{abstract}
The purpose of the study is to compare and evaluate the teachers' views upon the workout strategies for helping students motivate themselves in the classroom in terms of such qualities as autonomy, competence, relatedness and relevance. We interviewed with fifteen teachers in primary schools in city of Erzincan, Turkey and compared their views with those of forty-nine teachers from different countries. To obtain the data from other countries, we used the comments of foreign teachers having shared their views with us at Edutopia Blog Page launched by the author. We used a qualitative research method with semi structured interview form to gather data and to compare them with the comments in blog page. Having analyzed, compared and discussed the views of the teachers, we concluded that the teachers in different countries use the same strategies to help their students motivate themselves in the classroom, and the most important motivation strategies that the teachers use in their classrooms are positive relationship with the students, giving choice in academic and social activities, getting to know them, relatedness and autonomy.
\end{abstract}

Keywords Motivational Strategies, Relatedness, Relevance, Competence, Autonomy, Classroom Management

\section{Introduction}

Some students in primary and secondary schools struggle with appropriate ways to socialize communicate and establish good relations with others. Students having difficulties in socializing lack the basic social skills required to communicate and develop positive relationships with their friends in classroom or school environment. The problems of the students with difficulties in getting on well and establishing good relationships with others appear in many ways, including shyness, low self-esteem, anger, frustration or anxiety. In some cases, these students may be avoided by their peers for they are regarded as irritating, annoying and boring. Some adolescent students are not aware of social cues, thus provoking conflict as a means of getting the attention of others rather than being ignored. Irrespective of the conditions, the socially challenged student can be difficult to engage and may be identified as unmotivated. For this reason, the teachers should help these students motivate themselves so that they can establish good relationship, achieve goals and get academic success in the classroom.

\subsection{Motivation}

Motivation is the desire and energy to complete a task, achieve the target or reach a goal. In a general sense, Dörnyei and Otto[1] define motivation as the dynamically changing cumulative arousal in a person that initiates, directs, coordinates, amplifies, terminates, and evaluates the cognitive and motor processes whereby initial wishes and desires are selected, prioritised, operationalised and successfully or unsuccessfully acted out. Motivation includes biological, emotional, social and cognitive powers. These factors result in the formation of behaviour.

Motivation is described by Corbin [2] as an emotional reaction in which the learner sees a benefit, reward, or the potential for a positive reward in a task. He states that the extrinsic and intrinsic factors affecting motivation vary widely, however the factors such as relevance, control and choice, challenge, social interaction, anticipated sense of success, need, novelty, cognitive dissonance or discrepant events appear to influence motivation in learning.

There are two concepts of motivation, one of which is intrinsic motivation to take part in an activity for its own sake, another of which is extrinsic motivation to participate in an activity as a means to an end. Intrinsically motivated students, because they consider the task important and enjoyable, tend to be willing and active in their learning. They do not take part in learning activities for rewards or incentives; however, they find this kind of activities rewarding and pleasurable. Intrinsically motivated students do not need incentives because they regard the learning activities as satisfying and rewarding [3]. Extrinsically motivated students, on the other hand, become active in their learning because they understand that they will receive something of value if they 
do what the teacher desires or something that they dislike if they do not. Intrinsic motivation is related to academic achievement, creativity, reading comprehension and enjoyment, and using deep learning strategies, whereas extrinsic motivation has been linked to negative outcomes such as negative emotions, lack of academic achievement, and maladaptive learning strategies [4].

During the learning process, as the learner finds relevancy in the material and should know certain content, motivation for learning increases. Motivation for learning increases when the learner finds relevancy in the material or feels there is a need to know the particular content. Students get encouragements in lessons with which they connect, and apply them to their own life and experiences. In the case that the students exert some independence in the learning process they respond well. This is achieved by giving the student some control or input into his or her own education and offering choices in terms of projects, assignments, homework and other outcome assessments.

Students like to be challenged once there is the anticipated sense of success. Feeling confident in the learning process, having experienced success in the past and engaged in the subject, the students more probably persist as challenges emerge. Only by providing opportunities for students to work together, can teachers help students learn challenging material. Through collaboration as social interaction, students in small-group or large-group configurations, can share and exchange their ideas and learn from one another. Social interaction is likely to be helpful when new material is introduced and taught. Some students tend to get inspired by novelty, others are likely to experience cognitive dissonance as a consequence of resisting learning material in which there is a contradiction between the material and what they already know. Having the chance or opportunity to talk in groups, make brainstorm, exchange ideas, and solve problem together, the students are expected to be more receptive and open to new ideas. It is the teachers, mentors, instructors, coaches and family members that provide these chances and opportunities for the students to deal with their cognitive dissonance and problems with positive relations and communication with their peers and teachers. The key to achieve the attempts to motivate students is to understand and find out what motivates them

As motivation is the desire and energy moving an individual to take up and complete a task or achieve a goal, figuring out motivation styles can help teachers manage this power by adjusting their delivery methods and assignments. If instructional approaches are designed to be specific to various learning and motivational types, they will help develop a student's sense of belonging and connectedness, power and competence, freedom and fun.
The duties of the teachers who help students motivate themselves include respecting the students' learning styles, allowing for choices, applying appropriate instruction, individualizing instruction, focusing on strength, building on prior knowledge, acting friendly, being genuine, building positive relationship, giving priority to relatedness, autonomy, relevance, flexibility, collaboration and student interest

Interest is one of the motivational concepts that incorporate affective and cognitive factors to explain how and why individuals choose to engage in certain activities [5], [6]. Interest also has strong and yet not fully explained associations with the selection and pursuit of goals [7], [8], [9].

\subsection{Strategies for Motivation}

Effective and efficient teachers implement certain strategies to help students motivate themselves in classroom environment. As proper behaviours for motivation, the teachers show enthusiasm, establish a good relationship with students and show the students they care about them. As shown in Table 1, in order to recognize students' efforts, the teachers monitor students' progress and celebrate their achievements and victories, make sure grades reflect students' efforts and hard work; to promote students' self-confidence, they provide positive feedbacks for students, teach them learning techniques, and design tasks within the students' ability; to create a pleasant classroom climate, they bring in and encourage humour, create a supportive classroom climate that promotes risk-taking, use a short and interesting opening activity to start each class; to present tasks properly, they give clear instructions by modelling, give good reasons to students as to why a particular task is meaningful; to increase students' goal-orientedness, they help students develop realistic beliefs about learning, find out students' needs and build them into the curriculum, encourage them to set learning goals; to make the learning tasks stimulating, they break the routine by varying the presentation format, introduce various interesting topics, present various auditory and visual teaching aids, make tasks challenging; to familiarize students with related values, they introduce authentic cultural materials, remind students of the benefits of mastering in any discipline, encourage students to use the knowledge outside of the classroom; to promote group cohesiveness and group norms, they allow students to get to know each other, ask students to work toward the same goal, explain the importance of class rules; to promote learner autonomy, they adopt the role of facilitator, encourage peer teaching and group presentation, allow students to assess themselves [10]. 
Table 1. Strategies for Motivation and Teacher Activities

\begin{tabular}{|c|c|}
\hline Strategies for Motivation & Teacher activities \\
\hline For proper teacher behaviour & $\begin{array}{l}\text { show enthusiasm, } \\
\text { establish a good relationship with students } \\
\text { show the students they care about them }\end{array}$ \\
\hline To recognize students' efforts & $\begin{array}{l}\text { monitor students' progress and celebrate their achievements and victories, } \\
\text { make sure grades reflect students' efforts and hard work, } \\
\text { recognize students' efforts and achievements }\end{array}$ \\
\hline To promote students' self-confidence & $\begin{array}{l}\text { provide positive feedbacks for students, } \\
\text { teach them learning techniques, } \\
\text { design tasks within the students' ability }\end{array}$ \\
\hline to create a pleasant classroom climate & $\begin{array}{l}\text { bring in and encourage humour, } \\
\text { create a supportive classroom climate that promotes risk-taking, } \\
\text { use a short and interesting opening activity to start each class }\end{array}$ \\
\hline to present tasks properly & $\begin{array}{c}\text { give clear instructions by modelling, } \\
\text { give good reasons to students as to why a particular task is meaningful }\end{array}$ \\
\hline to increase students' goal-orientedness & $\begin{array}{l}\text { help students develop realistic beliefs about learning, } \\
\text { find out students' needs and build them into the curriculum, encourage them to set learning goals }\end{array}$ \\
\hline to make the learning tasks stimulating & $\begin{array}{l}\text { break the routine by varying the presentation format, } \\
\text { introduce various interesting topics, } \\
\text { present various auditory and visual teaching aids, } \\
\text { make tasks challenging }\end{array}$ \\
\hline to familiarize students with related values & $\begin{array}{l}\text { introduce authentic cultural materials, } \\
\text { remind students of the benefits of mastering in any discipline, } \\
\text { encourage students to use the knowledge outside of the classroom }\end{array}$ \\
\hline $\begin{array}{l}\text { to promote group cohesiveness and group } \\
\text { norms }\end{array}$ & $\begin{array}{c}\text { allow students to get to know each other, } \\
\text { ask students to work toward the same goal, } \\
\text { explain the importance of class rules }\end{array}$ \\
\hline to recognize students' efforts & $\begin{array}{l}\text { adopt the role of facilitator, } \\
\text { encourage peer teaching and group presentation, } \\
\text { allow students to assess themselves }\end{array}$ \\
\hline
\end{tabular}

(Adopted from Dörnyei and Csizer by Medina, 2014))

\section{Literature Review}

As early as in 1906, according to German philosopher Herbart[11], the cultivation of varied interest was a prior condition for learning and should be a primary goal of education. Dewey [12] extended this view by emphasizing that interest-based learning was different from learning with lack of interest. He maintained that interest was important to maintain self-initiated, content-related activities that result in pleasure, satisfaction, and learning. In the last two decades with a renaissance of interest research, educators and psychologists specifically recognized that interest is central in determining how we select and persist in certain activities, such as processing certain types of information in preference to others [13]. As indicated in the literature, interest facilitates learning [6],[14],[15]. Schiefele [16] and Schiefele and Krapp [17] demonstrated that this facilitation occurs especially with respect to qualitative measures such as deeper level learning.

Weinstein and DeHaan[18] argue in their research that motivational processes are responsible for initiating and directing human activity, in addition they energize behaviour, generate and increase task engagement, and direct actions toward certain ends or goals.

Lens et al. [19] show the positive effects of perceived instrumentality or utility for students' motivation and self-regulation. Adopting the traditional definition of intrinsic motivation and task orientation, instrumental motivation should be defined as a type of extrinsic motivation.

Akili [20] carried out a study providing insight for community colleges as educational institutions, for it has examined the motivations of net-generation student to stay in college. Moeed [21] conducted a research focusing on students' views about the three aspects of the study; learning, motivation, and assessment.

Motivational theorists [22],[23] in their studies describe the relationship between student motivation to learn and their approach to learning. They argue that the learner can have a deep or surface approach to learning which is dependent upon what they want and how they want to learn, as well as the nature of assessment of this learning.

Deci and Ryan [24] stated in their study that the relative autonomy of an individual's motivation is often driven by situational and domain specific factors; however, many relational experiences shape developmental trajectories stabilized into individual tendencies [25]

Wiseman and Hunt[26] argued in their study on the best practice in motivation and management in the classroom that teachers should understand their students' interests, styles of learning, and backgrounds, both academic and personal so as to be effective and meet the demands of society today.

It is argued in various studies that as children get older, 
their interest and attitudes toward academic activities may decline [27],[28],[29],[30] Such deterioration is reported to be characteristic of many adolescent students motivation, and creates special difficulties for them. As Rudolph et al [31] argued, understanding adolescents' adjustment difficulties in this critical stage of individual development may be essential for improving long-term educational outcomes. To understand the special problems created by adolescents' declining interest in many academic subjects such as mathematics and physics [32],[33],[34], it must be recognised that when children reach adolescence they are subject to a wide and sometimes conflicting array of social expectations. Within the framework of their school subjects, they are expected to take charge of their learning. Increasingly, schools are expecting students to become independent learners and to develop self-regulation strategies, both of which require purpose in learning [35],[36]. Simultaneously, specific organizational and management structures that regulate students' lives in middle school often serve to diminish student autonomy rather than promoting learner self-regulation and responsibility. This has been demonstrated in the work of Eccles and colleagues [37],[38]. Therefore, at a time when many students' interest in academic areas is declining, they are being expected to show self-regulation and purpose in their learning while at the same time they need to conform to relatively restrictive and controlling school organizational structures.

\section{Material and Method}

\subsection{Problem Statement and Purpose}

The aim of the study on the teachers' views upon the strategies for helping students motivate themselves in the classroom is to determine the similar and the different views of primary school teachers from various countries around the world, and to evaluate them in a cross cultural context. In order to determine and compare what strategies the teachers use for helping their students motivate themselves in classroom environment, we asked them an open ended question with four sub-sections; "What do you usually do to help your students motivate themselves in classroom environment as qualities of (1) Autonomy; (2) Competence; (3)Relatedness; and (4)Relevance.

\subsection{Methods and Research Design}

We used a qualitative research method to determine and interpret teachers' views and intention in cross-cultural setting. We chose this kind of methodological approach, as qualitative research method enables researchers to interpret and make judgement about immeasurable data [39]. We conducted this research in a particular setting through Edutopia Blog and a group of Primary School teachers in
Erzincan City. For this reason we relied on case study design for the purpose of our enquiry.

\subsection{Participants}

Participants were fifteen Primary School teachers working in various Primary Schools under the Authority of National Education in Erzincan City, Turkey and forty-nine Primary School teachers having written comments on Edutopia Blog launched by the author. We preferred and used easy accessible sample technique in the research, as it increases the speed of collecting data and enables researchers to access the sample easily [40]. We obtained the data from 15 classroom teachers who admitted to be involved in the interview for the research, and 49 primary school teachers from various countries replying to the questions and writing their comments on Blog page. The participants were asked whether they were contented to answer to the questions, and then we applied the tool. The names of the teachers are coded with letters and numbers.

\subsection{Research Instrument}

In the study, in order to gather data from classroom teachers and to compare the data with blog comments, we used the tool with semi structured interview form, which is one of the main components of qualitative research, for it is understanding people from their own frames of reference and experiencing reality as they experience it. We asked one open ended question to the participants, which is "What do you usually do to help your students motivate themselves in classroom environment as qualities of autonomy, competence, relatedness and relevance?" The question was designed in accordance with the comments of the participants for Edutopia Blog about 'Strategies for Helping Students Motivate Themselves' launched by the author.

\subsection{Data Analysis}

We obtained the data with the help of the interview with the participants and the comments they wrote in Blog page; the data were then transferred and digitalized into computer in order to form digital data. We used content analysis with the percentage and frequency values.

\section{Findings}

The findings that we obtained from Primary School and Secondary School teachers for the question in the semi-structured interview form, the strategies for motivation that we extracted from the replies and comments of the participants, and the comments made by the participants teachers at the Edutopia blog are given below. 
Table 2. Strategies for Motivation implemented by Participants

\begin{tabular}{|c|c|c|c|}
\hline $\begin{array}{c}\text { Strategies for } \\
\text { Motivation }\end{array}$ & $\begin{array}{c}\text { Number of the } \\
\text { Participants }\end{array}$ & $\begin{array}{c}\text { Number of the } \\
\text { Supporters }\end{array}$ & Percent (\%) \\
\hline Autonomy & 64 & 41 & 64.06 \\
\hline Relevance & 64 & 40 & 62.50 \\
\hline Relatedness & 64 & 40 & 62.50 \\
\hline Competence & 64 & 38 & 59.37 \\
\hline Give choice & 64 & 15 & 23.43 \\
\hline Relationship & 64 & 8 & 12.50 \\
\hline Get to know & 64 & 8 & 12.50 \\
\hline Family factor & 64 & 5 & 7.81 \\
\hline Reward & 64 & 4 & 6.25 \\
\hline Genuine & 64 & 4 & 6.25 \\
\hline Trust & 64 & 3 & 4.68 \\
\hline Responsibility & 64 & 3 & 4.68 \\
\hline Freedom & 64 & 3 & 4.68 \\
\hline Flexibility & 64 & 3 & 4.68 \\
\hline Passionate & 64 & 2 & 3.12 \\
\hline Humour & 64 & 2 & 3.12 \\
\hline Collaboration & 64 & 2 & 3.12 \\
\hline Act friendly & 64 & 2 & 3.12 \\
\hline
\end{tabular}

The question was "What do you usually do to help your students motivate themselves in classroom environment as the quality of autonomy?" The sample statements for this question are given as followings.

C.C. (Primary School teacher): “.... I also find autonomy very interesting. It's a wonderful idea to give students choices in terms of coming up with their own homework assignments and projects. They could even create an idea as an initial homework assignment, then choose from the top four ideas from their classmates. I love it!..."

J.G. (Secondary School teacher): “...we really underrate the significance of having method in education, based on genuine principles that do work. Particularly I would stimulate an interest on autonomy value. I am of the belief that autonomy allows learners to achieve on their own way and genre. ..."

L.S. (Primary School teacher): “...The strategy to which I actually related was supplying freedom of choice for students to encourage learner autonomy. Taking responsibility for their learning and studying and being involved in the decision-making process, they are more interested in their duties and posts. I began providing choice boards for my first graders, and many times, I try to allow students to choose their desired production for an assignment. For example,.... Some students want to complete a story map, some a comic strip, and others prefer to write a paragraph and add a picture at the end. Having engaged in the work period they feel excited to share their work..."

A.T. (Primary School teacher): “... at times all that I have a hard time as a teacher is the autonomy aspect .... As a 2nd grade teacher, I find it to be a difficult balance of letting students guide their own learning ...."

R.O. (Primary School teacher): “...Students in this century pay little attention to lessons in courses owing to lack of motivation, therefore only if students realise what their actual aim in taking up their education, will they be motivated to pay attention to learning and studying their lessons.... I completely agree with autonomy, competence, relatedness and relevance as the key qualities for the motivation of students..."

D.M. (Maths teacher at Secondary School): “...I am always in search for strategies to help students motivate themselves and to improve their problem-solving skills... I agree that providing autonomy is so engaging to reluctant unmotivated pupils.... I use choice boards often to provide a "structured" freedom of choice. ..."

As seen in the given statements and comments of the participants over autonomy as a quality for motivation, $64.06 \%$ of the participant teachers in the study implement the quality of autonomy for motivation. They are of the opinion that autonomy allows learners to achieve on their own way and genre, it is quite engaging to reluctant and unmotivated learners, and learner autonomy can be achieved through providing freedom of choice. According to Ferlazzo[41] providing freedom of choice for students in classroom environment by their teachers is one strategy for enhancing and promoting learner autonomy. Such educators as teachers, mentors, coaches generally view this idea of choice through the scope of both organizational and procedural choice. Organizational choice might mean students with a voice in seating assignments or members of their small learning groups, whereas procedural choice could include a choice from a list of homework assignments and what form a final project might take- a book, booklet, poster, or parody.

Wiseman and Hunt[26] have argued in their research that Physical, emotional, interpersonal, and intellectual qualities of an individual impact what he or she chooses to do, so the humanist view entirely focuses on them. From the humanistic point of view, to motivate someone means to stimulate and encourage the student's inner resources such as sense of competence, self-esteem, autonomy, and self-actualization. According to the humanist, there is no such thing as an unmotivated student; all students are motivated.

McCombs[42] states in his research that motivation is related to whether students have opportunities to be autonomous, thus to make important academic choices. Having choices enables students to feel so powerful that they can have control over their own learning, which leads them to develop a sense of responsibility, self-regulation and self-motivation

One of the significant and essential strategies that one of the participant teachers in the study recommends is letting freedom of choice for students so as to encourage learner autonomy. The more responsibilities they take for their learning and studying process and for being involved in the decision-making process, the more they are interested in and 
fulfil their duties and posts. That is why most teachers allow students to choose their desired production for an assignment. In one statement, on the other hand, it is pointed out that providing autonomy is likely to enhance engagement in learning activities.

The statements of the participants as replies to the second sub-question of "What do you usually do to help your students motivate themselves in classroom environment as the quality of competence?" The sample statements for this question are given as followings.

R.D. (Secondary School teacher): “.... I have found out that relevance works best for me. I am proud of myself in getting to know my students. I am of the belief that building trust is essential strategy to motivate students in the classroom. In addition, making learning relevant is also essential, sometimes it seems not that easy, still, when achieved, it makes a profound impact on student achievement. I am trying and incorporating more autonomy and competence in my classroom..."

N.K. (Secondary School teacher): “... when I meet the needs of my students for autonomy, connectedness and competence, I observe that their motivation level increase, which makes me extremely happy. I try to establish good connection and relationship with them, and in return for this, they make me happy with their achievement in lessons.... All students can be motivated if you do it properly... I remark the term properly because easy tasks doesn't stimulate students sense of competence "

S.A. (Primary School teacher): “...I strongly believe that academic emotions have a great influence on outcomes of learning. Academic emotions can contribute to school achievement, academic and social interaction, wellbeing and self-regulation, thus affecting learning. When I teach them how to manage their academic emotions, they learn self-regulating, and as their sense of competence improves, they begin to feel more positive...."

P.T. (Primary School teacher): “... Among my students are deep learners, strategic learners and surface learners. I hardly have difficulty teaching deep learners, I enjoy and have great pleasure while teaching them, as they are intrinsically motivated, whereas I try to motivate strategic learners by reward, as they react well to competition... But, family involvement is also essential for the sense of competence..."

From the statements and the comments of the teachers, $59.37 \%$ of them implement the quality of competence for motivation. According to them, three innate psychological needs, such as competence, autonomy and relatedness are very important for students. Their sense of competence as well as self-esteem, self-actualization and autonomy are the students' inner resources. Student behaviours and attitudes towards learning are affected by the need for a sense of competence, virtue, power and significance. Teaching competence to the strategic students does not only reduce the influence of negative factors, but also prevent misbehaviours resulting from poor instruction.

Some students are motivated by the appropriate use of rewards and it is possible to observe these rewards bring about positive changes in their behaviours and attitudes towards learning. As one of the participants in the study states, the use of praise for expected achievement and rewards that provide increasing competence can contribute to increased intrinsic motivation [43].

From the humanistic point of view, motivating gives rise to encouragement of students' inner resources, such as self-esteem, self-actualization, autonomy and sense of competence. Some students may be motivated much, while others less, but there is a fact that all students can be motivated if the motivation is done properly and in accordance with their needs. As argued in some researches, higher levels of motivation are obvious when the teachers meet student needs for belonging and social connectedness, autonomy and self-direction, and competence [44].

In the statement of one teacher in our study, she argues that family involvement is essential for the sense of competence and some researchers have done the same statements in their studies that family involvement in the education of their children both at home and at school creates better learning outcomes for children [45],[46]. Across a range of research studies in different national and cultural contexts, higher levels of parental involvement are associated with children's higher achievement and engagement with school [47],[48]. As can be seen in the studies by these authors and the statements of participant teachers in the study, there are important links between parenting and children's academic and behavioural competence at school. From this perspective, children's school-related development can be said to be influenced by parental beliefs, expectations, and behaviours to ensure academic socialisation.

In the studies carried out by Gottfried[49] and Harter[50] it is argued that students like to get academic tasks and tend to learn more as long as they feel competent and expect success [51], [52],[53]. As one of the participant teachers in the study points out, if students are given easy tasks for learning, they have difficulty developing a sense of competence.

To determine the teachers' views on relatedness as a motivational quality, we asked "What do you usually do to help your students motivate themselves in classroom environment as the quality of relatedness?" The sample statements for this question are given as followings.

N.R.H (Secondary School teacher): “..I pay much attention to relatedness. I am aware of the importance of "acting friendly". I give a smile or use a little irony, and they laugh from the belly and re-engage. A soft touch on the shoulder is enough for me to build a positive relationship with them. Even my principal and colleagues have noticed how effective this strategy is in my classroom. One simple touch can let the most unfocused student know how I care about them and their learning...."

H. H. B. (Secondary School teacher) “...I strongly believe that feeling competent, autonomous as well as self-expressive is important in one's life. I observe these 
qualities in different levels in my students; some good at the sense of competence, the other at autonomy, and one another at self-expression. In accordance with the student characteristics, I try to adjust their needs of, especially, relatedness, competence and autonomy..."

M. O. (Primary School teacher) "...I always try to show that I care about my students in the classroom as equals. Therefore I deliberately support their relatedness needs. I do respect my students enough to let them feel to make their own choice. Sometimes I apply different strategy to support their relatedness, for instance I encourage them to establish good friendship, relationship or partnership with others. I show my sensitive to their needs of relatedness..."

From the comments in the blog and the statements given to the question, $62.50 \%$ of the participant teachers in the study implement the quality of relatedness for motivation. The teachers motivate their students through two theories; Self-determination Theory and Achievement Goal Theory. The former is supposed to be based on the degree the students are motivated to fulfil three needs of relatedness, autonomy and competence [54]. The latter is related to the target of achievement expected in classroom. The aim is focused on improving learning [55], and the teachers believe that achievement is possible with academic effort.

The student's adjustment, membership, and eventual success are related to such innate psychological needs as relatedness, autonomy and competence. Wiseman[26] argues that relatedness, according to self-determination theory, is related to the feeling of being connected to others in social environment and feeling worthy of love and respect. Relatedness is not only crucial for students' well-being and health, but it is also essential for students' positive motivation. Acting friendly, smiling, touching on shoulder, warm greetings and irony are enough for the students to be motivated and build good relationship with the teacher. For them to be well-being is also important for academic success.

As remarked in the statements of the participant teachers in the study, autonomy, relatedness and competence go together. According to Sheldon[56], there is no conflict between them, moreover it is rather difficult to separate autonomy from relatedness. Almost every student more or less experiences relatedness, autonomy, competency and relevance in classroom environment.

In order to detect the teachers' views on relevance as a motivational quality, we asked "What do you usually do to help your students motivate themselves in classroom environment as the quality of relevance?" The sample statements for this question are given as followings.

F. K (Secondary school teacher)".. I often make my students write down notes of the subject. I try to convince them to know that the course notes are very important and of great asset to the examination. I encourage them to share the notes with each other. In this way, the course and the exam have an ongoing relevance, for I believe that relevance for others functions and acts to justify the student involvement or participation..."

C. C. (Secondary School teacher) “... I often allow my students to connect how the lessons are relevant to their own lives, which, according to me, is a key aspect of the learning process. In secondary school setting, a big difficulty is that the students choose not to see the relevance that a subject they should learn has in their lives. If they form connections on relevance by themselves, motivation increases by itself. I also find autonomy to be very interesting and essential. It's a good idea to give students choices of what they do as an academic task in the classroom...."

A.B. (Secondary School teacher) "...I really like the relevance in motivating my students, for I always plan on getting my students to complete a reflective question each assessment period. I like to see that students are aware of why lessons are significant for their own lives. I teach Spanish and practicing grammar can be tedious and tough..."

Such factors as relevance, control and choice, challenge, social interaction, the chance to work with others, anticipated sense of success, need, novelty, cognitive dissonance or discrepant events are very important to influence motivation in learning. If the students can find relevancy in educational materials, then their motivation for learning increases. The teachers try to get their students to find encouraging and motivating factors in lessons so that they can apply to their own lives and experiences. If the students are provided input into their own learning tasks and exert independence in learning process, they are motivated to respond well and they catch academic success easily.

From the statements of the participant teachers in the study, $62.50 \%$ of the participant teachers implement the quality of relevance for motivation. They do their best to motivate their student by trying to persuade them to take the course notes into consideration, to make their students share the course notes, thus providing ongoing relevance by sharing the notes between each other and creating a collaborative condition.

In some studies on this topic, Cothran and Ennis[57] determined that the students would be disinclined to take part in classroom activities unless they perceived social relevancy with their teachers. The students develop lack of engagement when they perceive less connection between curriculum and their expectations. As long as the students are convinced that the teachers care for them and value them, they become more eager and willing to participate in school activities and learning process.

\section{Discussion and Conclusion}

As motivation directs behaviour and attitude toward particular targets, the teachers should recognize how motivation relates to successful learning for their students as well as how it relates to their own behaviours and attitudes towards learning

Compared to the other dimensions of learning process, competence motivation is of the strongest relationship to observed classroom autonomy. The teachers, therefore, 
should attach importance to self-determination, choice, initiative for the quality of autonomy, and flexibility, reactivity and modulation of emotions for competence motivation.

Competence motivation is associated with creative, generative, engaged, and initiative behaviours. They enable the students to connect with learning opportunities. So the students who are lack of interest in learning and academic activities should be made to engage in social environment and to feel worthy of love and respect.

The teachers should make a point of cognitive processes as they are affected by motivation. Thus teacher should determine what students need in learning process, what they pay attention and what they are eager to do.

As higher levels of parental involvement are associated with children's higher achievement and engagement with school, the teachers should implement parental involvement in students' learning process so that the motivation efforts could be a success.

The teachers should know that understanding, exploring and determining academic emotions of the students are extremely important, therefore they should be aware of students' quality to be sure of learning outcomes, as well as achievement and social interactions in a school environment.

Students with negative views of their competence and low expectations for success should be encouraged to overcome learning difficulties, because their beliefs about their competencies and expectations for success have a direct effect on their intellectual engagement. In the case that the teachers establish good relationship and friendship with their students, the students' concerns about their competence reduce. The teacher should account for relatedness quality of motivation in such situation.

As a consequence, so as to build and support motivation, the teachers should realise that students become self-motivated if they plan and organise what they need, if there is a personal aim that they have identified, if the work progresses and continues without breaks. On the other hand, the teachers should highlight the purpose of the activity for motivation as to what task should be involved in and what teaches the student best, the teachers should encourage students to set personal goals, ensure students to review their progress, encourage students to compete against themselves and others, give students some independence as autonomy.

\section{REFERENCES}

[1] Dörnyei, Z. and Ottó, I. (1998) Motivation in action: A process model of L2 motivation. Working Papers in Applied Linguistics, Thames Valley University, London 4: 43-69.

[2] Corbin, B. (2008). Unleashing the Potential of the Teenage Brain. Corwin Press, California, USA.

[3] Anderman, E., \& Anderman, L. (2010). Motivating children and adolescents in schools. Columbus, $\mathrm{OH}$ :
Merrill/Prentice-Hall.

[4] Corpus, J., McClintic, G., M., \& Hayenga, A. (2009). Within-year changes in children's intrinsic and extrinsic motivational orientations: Contextual predictors and academic outcomes. Contemporary Educational Psychology, 34, 154166.

[5] Hidi, S., \& Berndorff, D. (1998). Situational interest and learning. In L. Hoffman, A. Krapp, K. Renninger, \& J. Baumert (Eds.), Interest and learning: Proceedings of the Seeon Conference on interest and gender (pp. 74-90). Kiel, Germany: IPN.

[6] Krapp, A. (2000). Interest and human development during adolescence: An educational psychological approach. In J. Heckhausen (Ed.), Motivational Psychology of Human Development (pp. 109-128). Elsevier. Amsterdam

[7] Hidi, S., \& Harackiewicz, J. (2000). Motivating the academically unmotivated: A critical issue for the 21 st century. Review of Educational Research, 70, 151-179.

[8] Krapp, A. (2002) An educational-psychological theory of interest and its relation to SDT. In Deci, E.L. and Ryan, R.M., Handbook of Self-Determination Research. Rochester, NY: The University of Rochester Press: 405-27.

[9] Sansone, C., \& Harackiewicz, J. M. (1996). "I don’t feel like it": The function of interest in self-regulation. In L. L. Martin \& A. Tesser (Eds.), Striving and feeling: Interactions among goals, affect, and self-regulation (pp. 203-228). Mahwah, NJ: Erlbaum.

[10] Medina S. L., (2014). Motivation Conditions in a Foreign Language Reading Comprehension Course Offering Both a Web-Based Modality and a Face-to-Face Modality, Profile Issues in Teachers' Professional Development, vol.16 no.1 Bogotá Jan./June 2014

[11] Herbart, J. F. (1906/1965). Allgemeine Pädagogik, aus dem Zweck der Erziehung abgeleitet. In J. F. Herbart, Pädagogische Schriften (Vol. 2, pp. 9-155). Düsseldorf, Germany: Küpper.

[12] Dewey, J. (1913). Interest and effort in education. New York: Houghton Mifflin.

[13] Hidi, S. (1990). Interest and its contribution as a mental resource for learning. Review of Educational Research, 60, 549-571.

[14] Renninger, K. A. (2000). How might the development of individual interest contribute to the conceptualization of intrinsic motivation? In C. Sansone \& J. M. Harackiewicz (Eds.), Intrinsic and extrinsic motivation: The search for optimal motivation and performance. New York: Academic Press

[15] Renninger, K. A., \& Hidi, S. (2002). Student interest and achievement: Developmental issues raised by a case study. In A. Wigfield \& J. Eccles (Ed.), Development of achievement motivation (pp. 173-195). San Diego, CA: Academic Press

[16] Schiefele, U. (2001). The role of interest in motivation and learning. In J. M. Collis \& S. Messick (Eds.), Intelligence and personality: Bridging the gap in theory and measurement (pp. 163-194). Mahwah, NJ: Erlbaum.

[17] Schiefele, U., \& Krapp, A. (1996). Topic Interest and Free Recall of Expository Text. Learning and Individual 
Differences, 8, 141-160.

[18] Weinstein, N. \& DeHaan, C. R. (2014). On the Mutuality of Human Motivation and Relationship, Human Motivation and Interpersonal Relationships: Theory, Research, and Applications, Springer Press. Dordrecht

[19] Lens W., Simons J., Dewitte S. (2002). The Role of Students' Future Time Perspective and Instrumentality Perceptions for Study Motivation and Self-Regulation, Academic Motivation of Adolescents. Pajares F. and Urdan T.(Eds). Information Age Publishing, Greenwich, Connecticut

[20] Akili, S.M. (2014). Net-Generation Student Motivation to Attend Community College, University Press of America, London, United Kingdom.

[21] Moeed, A., (2015). Science Investigation, Student Views about Learning, Motivation and Assessment, Springer Briefs in Education, London

[22] Entwistle, N. (2005). Learning and studying: Contrasts and influences. Retrieved September 8, 2005, from $\mathrm{http} / / /$ www.newhorizons.org/future/Creating the Future/crfu $\mathrm{t}$ entwi9stle.html.

[23] Entwistle, N., \& Ramsden, P. (1983). Understanding student learning. London: Croom Helm

[24] Deci, E. L., \& Ryan, R. M. (2012). Self-determination theory. In P. A. M. Van Lange, A. W. Kruglanski, \& E. T. Higgins (Eds.), Handbook of theories of social psychology: Vol. 1 (pp. 416-437). New York

[25] La Guardia, J. G., \& Ryan, R. M. (2007). Why Identities Fluctuate: Variability in Traits as a Function of Situational Variations in Autonomy Support. Journal of Personality, 75, $1205-1228$.

[26] Wiseman, D. G. \& Hunt G. H., (2015). Practice in Motivation and Management in the Classroom, Third edition. Charles C Thomas Publisher, Ltd. Illinois, USA

[27] Anderman, E. M., \& Maehr, M. L. (1994). Motivation and Schooling in the Middle Grades. Review of Educational Research, 64, 287-309.

[28] Haladyna, T., \& Thomas, G. (1979). The attitudes of elementary school children toward school and subject matters. Journal of Experimental Education, 48, 18-23.

[29] Harter, S. (1981). A new self-report scale of intrinsic versus extrinsic orientation in the classroom: Motivational and informational components. Developmental Psychology, 17, $300-312$

[30] Wigfield, A., \& Eccles, J. S. (1992). The development of achievement task values: A theoretical analysis. Developmental Review, 12, 265-310.

[31] Rudolph, K. D., Lambert, S. F., Clark, A. G., \& Kurlakowsky, K. D. (2001). Negotiating the Transition to Middle School: The role of self-regulatory processes. Child Development, 72, 929-946

[32] Eccles, J.S., Wigfield, A. \& Schiefele, A. (1998) Motivation to succeed. In Damon, W. and Eisenberg, N. (eds), Handbook of Child Psychology, 5th Ed, Vol. 3: Social, Emotional, and Personality Development. New York: John Wiley \& Sons: 1017-95.

[33] Epstein, J. L., \& McPartland, J. M. (1976). The concept and measurement of the quality of school life. American Educational Research Journal, 13, 15-30.

[34] Hoffmann, L., \& Haussler, P. (1998). An intervention project promoting girls' and boys' interest in physics. In L. Hoffman, A. Krapp, K. Renninger, \& J. Baumert (Eds.), Interest and learning: Proceedings of the Seeon Conference on interest and gender (pp. 301-316). Kiel, Germany: IPN.

[35] Walker, J. M. T. (2001). Age-related patterns in student motivation and strategy use during homework: Implications for research on self-regulated learning. Unpublished manuscript.

[36] Zimmerman, B. J. (1989). A social-cognitive view of self-regulated learning. Journal of Educational Psychology, 81, 329-339.

[37] Eccles, J. S., \& Midgley, C. (1989). Stage-environment fit: Developmentally appropriate classrooms for young adolescents. In C. Ames \& R. Ames (Eds.), Research on motivation in education: Goals and cognitions (Vol. 3, pp. 139-186). San Diego: Academic Press.

[38] Maehr, M. L. \& Midgley, C. (1996). Transforming school cultures. Boulder, CO: Westview Press.

[39] O’Tool, J., Beckett, D. (2010). Educational Research: Creative Thinking and Doing. Victoria: Oxford University Press.

[40] Yıldırım, A., Şimşek, H. (2006). Qualitative Research Methods in Social Sciences. Seçkin Press. Ankara

[41] Ferlazzo L., (2015). Building a Community of Self-Motivated Learners: Strategies to Help Students Thrive in School and Beyond. Taylor Francis, Routledge, New York, USA

[42] McCombs, B., (2016). Developing Responsible and Autonomous Learners: A Key to Motivating Students, American Psychological Association. http://www.apa.org/edu cation/k12/learners.aspx

[43] Cameron, J., Pierce, W., \& Banko, K. (2005). Achievement-based rewards and intrinsic motivation: A test of cognitive mediators. Journal of Educational Psychology, 97, 641-655.

[44] Battistich, V., Solomon, D., Kim, D., Watson, M., and Schaps, E. (1995). Schools as communities, poverty levels of student populations, and students' attitudes, motives, and performance: A multilevel analysis. American Educational Research Journal, $32,627-658$

[45] Henderson, A. T., and Mapp, K. L. (2002). A new wave of evidence: The impact of school, family and community connections on student achievement. Austin, TX: Southwest, Educational Development Laboratory.

[46] Jeynes, W. H. (2005). A meta analysis of the relations of parental involvement to urban elementary school student academic achievement. Urban Education, 40, 237-269.

[47] Pomerantz, E. M., Moorman, E. A., and Litwack, S. D. (2007). The how, whom, and why of parents' involvement in children's academic lives. Review of Educational Research, 77(3), 373-410.

[48] Reynolds, A., and Clements, M. (2005). Parental involvement and children's school success. In E. N. Patrikakou, R. P. Weissberg, S. Redding, and H. J. Walberg (Eds.), School-family partnerships: Promoting the social, emotional, 
and academic growth of children (pp. 109-127). New York: Teachers College Press.

[49] Gottfried, A. (1990). Academic intrinsic motivation in young elementary school children. Journal of Educational Psychology, 82, 525-538

[50] Harter, S. (1992). The relationship between perceived competence, affect, and motivational orientation within the classroom: Process and patterns of change. In A. Boggiano and T. Pittman (Eds.), Achievement and motivation: A social-developmental perspective (pp. 77-114). New York: Cambridge University Press.

[51] Bandura, A. (1993). Perceived self-efficacy in cognitive development and functioning. Educational Psychologist, 28, $117-148$

[52] Schunk, D. (1995). Self-efficacy and education and instruction. In J. Maddux (Ed.), Self-efficacy, adaption, and adjustment:
Theory, research, and application (pp. 281-303).

[53] Pajares, F. (1996). Self-efficacy beliefs in academic settings. Review of Educational Research, 66, 543-578.

[54] Ryan, R.M. and Deci, E.L. (2000) Intrinsic and extrinsic motivations: Classic definitions and new directions. Contemporary Educational Psychology 25: 54-67.

[55] Ames, C. (1992) Classrooms, goals, structures and student motivation. Journal of Educational Psychology 84: 267-71.

[56] Sheldon K., (2008). Positive Motivation: A six-week course. British Library Cataloguing-in-Publication Data, United Kingdom.

[57] Cothran, D., and Ennis, C. (1999). Alone in a crowd: Meeting students ${ }^{6}$ needs for relevance and connection in urban high school physical education. Journal of Teaching in Physical Education, 18, 234-247. 